\title{
Current status and future development of solvent-based carbon capture
}

\author{
Eni Oko ${ }^{1} \cdot$ Meihong Wang ${ }^{1} \cdot$ Atuman S. Joel $^{2}$
}

Received: 26 October 2016/Revised: 24 January 2017/Accepted: 16 February 2017/Published online: 27 February 2017

(C) The Author(s) 2017. This article is published with open access at Springerlink.com

\begin{abstract}
Solvent-based carbon capture is the most commercially-ready technology for economically and sustainably reaching carbon emission reduction targets in the power sector. Globally, the technology has been deployed to deal with flue gases from large scale power plants and different carbon-intensive industries. The success of the technology is due to significant R\&D activities on the process development and decades of industrial experience on acid gas removal processes from gaseous mixtures. In this paper, current status of PCC based on chemical absorption-commercial deployment and demonstration projects, analysis of different solvents and process configurations-is reviewed. Although some successes have been recorded in developing this technology, its commercialization has been generally slow as evidenced in the cancellation of high profile projects across the world. This is partly due to the huge cost burden of the technology and unpredictable government policies. Different research directions, namely new process development involving process intensification, new solvent development and a combination of both, are discussed in this paper as possible pathways for reducing the huge cost of the technology.
\end{abstract}

Keywords Post-combustion $\mathrm{CO}_{2}$ capture $(\mathrm{PCC}) \cdot$ Chemical absorption $\cdot$ Solvents $\cdot$ Process intensification

\section{Introduction}

Carbon capture and storage (CCS) is considered the most sustainable and economic option for cutting down $\mathrm{CO}_{2}$ emissions from large stationary sources such as coal-fired power plants and other carbon-intensive industries (e.g. refineries, steelworks, cement plants) due to the trilemma of ensuring clean, secure and affordable energy sources (IPCC 2014). CCS technology involves capturing $\mathrm{CO}_{2}$ from these sources and transporting them to underground storage sites, namely saline aquifer and depleted oil and gas reserves, where they are either stored permanently and

Meihong Wang

Meihong.Wang@sheffield.ac.uk

1 Department of Chemical and Biological Engineering, University of Sheffield, Sheffield S1 3JD, UK

2 School of Engineering, University of Hull, Hull HU6 7RX, UK prevented from entering the atmosphere or used for enhanced oil recovery (EOR) purposes (IPCC 2014). Without CCS, cost of $\mathrm{CO}_{2}$ emission reduction in these sectors may be up to 70\% more (CCSA 2011).

CCS can be implemented using different approaches, namely post-combustion (PCC), pre-combustion and oxyfuel capture (Wang et al. 2011). In the different approaches, there are different processes for separating $\mathrm{CO}_{2}$ from gas mixtures such as chemical absorption, physical absorption, adsorption and membrane separation. Other emerging processes such as chemical looping (Olaleye and Wang 2014) and calcium looping (Blamey et al. 2010) also have good potentials. Implementing CCS through PCC based on chemical absorption (Fig. 1) offers some benefits compared to other processes (IEAGHG 2014). These include reliance on established technologies and capacity to be retrofitted to existing power plants/industrial plants with minimal modifications. PCC processes based on chemical absorption (with conventional amine solvents) is also currently at a technology readiness level (TRL) of 6-8 


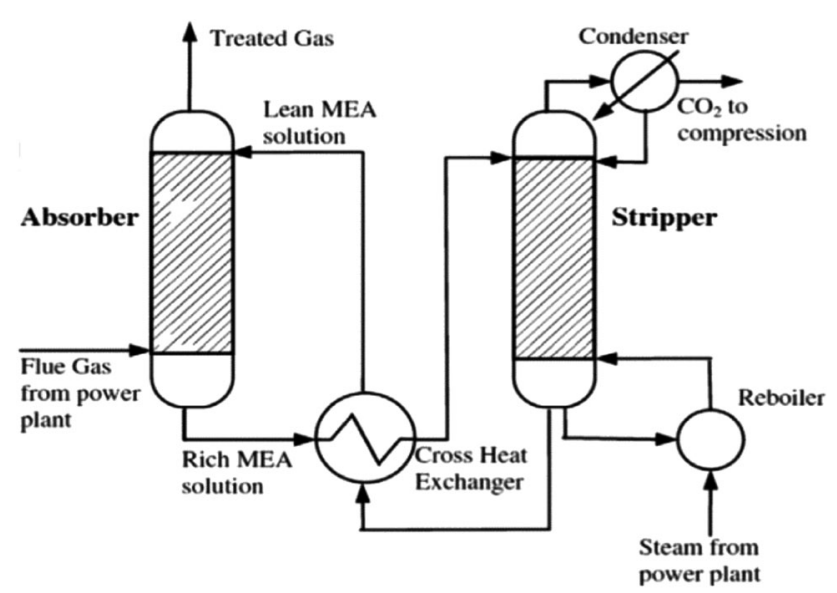

Fig. 1 Diagram of PCC process based on chemical absorption (IPCC 2005)

(TRL 6-fully integrated pilot tested in a relevant environment, TRL 7-subscale demonstration, fully functional prototype, TRL8 - commercial demonstration) (IEAGHG 2014). Consequently, many first generation CCS projects are expected to be implemented through PCC based on chemical absorption (Wang et al. 2011). A detailed description of the process is given in Wang et al. (2011).

Although several CCS projects using PCC based on chemical absorption have been completed in the past, the capital and operating cost of the process remains unacceptably high and substantial research efforts have been devoted to address this need. The aim of this paper is to provide an update on current and predicted future research and development (R\&D) activities on PCC based on chemical absorption. These include pilot plant testing, demonstration project overview, and other commercial activities, assessment of the process configurations (flowsheet development) and different solvents used in the process. These discussions set this paper apart from other related reviews such as Wang et al. (2011) and BootHandford et al. (2014).

\section{Process configurations}

Alternative process configurations have been developed by adding extra equipments (e.g. heat exchangers, compressors, flash drum etc.) to the conventional process (Fig. 1). Typical examples include configurations involving absorber inter-cooling, multi-pressure stripping and split-flow $\mathbf{a}$

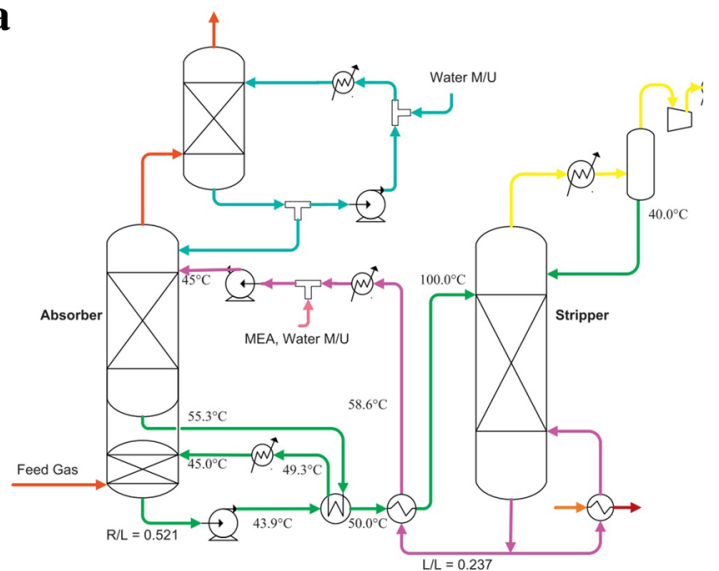

b

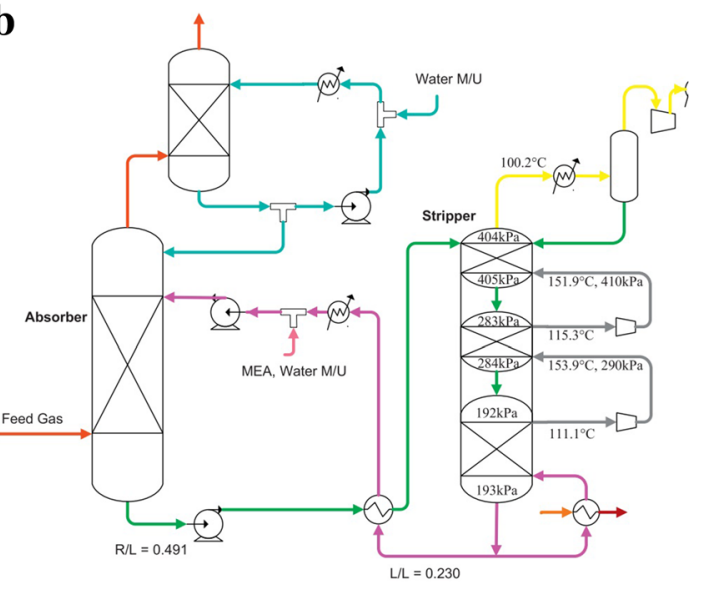

C

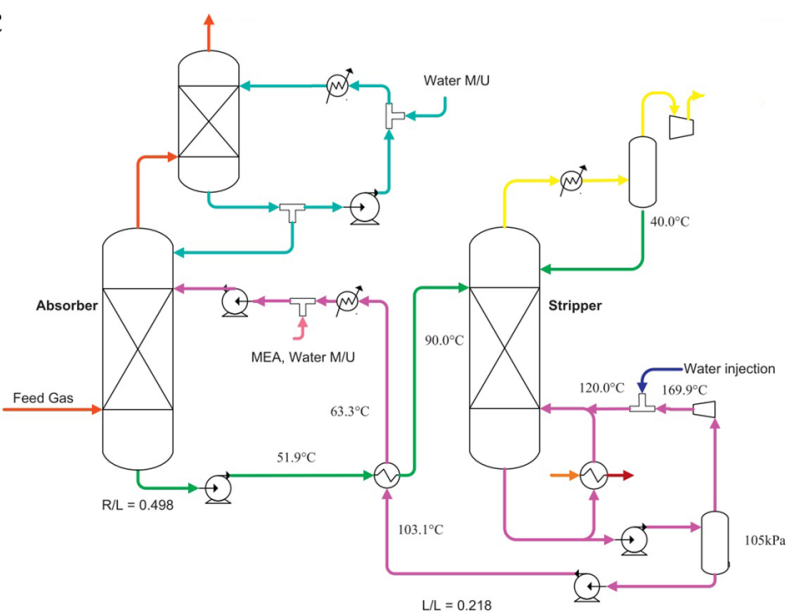

Fig. 2 Alternative configurations a absorber inter-cooling, b multipressure stripping, $\mathbf{c}$ split solvent flow, d lean solvent flash (Ahn et al. 2013) 
Table 1 Energy consumptions for different process configurations (Ahn et al. 2013)

\begin{tabular}{lll}
\hline Configuration & $\begin{array}{l}\text { Reboiler duty } \\
\left(\mathrm{MJ}_{\mathrm{th}} / \mathrm{kg}_{\mathrm{CO} 2}\right)\end{array}$ & $\begin{array}{l}\text { Total energy } \\
\text { demand }\left(\mathrm{MJ} / \mathrm{kg}_{\mathrm{CO} 2}\right)\end{array}$ \\
\hline Conventional & 3.52 & 1.380 \\
Absorber intercooling & 3.11 & 1.257 \\
Multi-pressure stripping & 3.17 & 1.353 \\
Split amine flow & 3.09 & 1.252 \\
Lean amine flash & 2.76 & 1.220 \\
\hline
\end{tabular}

(Fig. 2) among others (Fisher et al. 2007; Ahn et al. 2013; Boot-Handford et al. 2014). Thermodynamic analysis of these configurations with $30 \mathrm{wt} \%$ monoethanolamine (MEA) solvent shows that they are more energy efficient than the conventional configuration (see Table 1). However, due to the extra instrumentation/equipment, their capital costs will be predictably higher. The Boundary Dam commercial PCC plant in Canada incorporates an absorber inter-cooler configuration (IEAGHG 2015).

\section{Solvents}

MEA solution (30 wt\% or less MEA) is generally considered a benchmark solvent for PCC based on chemical absorption process. The oldest commercial PCC processes, Kerr-McGee/ABB Lummus Crest process and Fluor Daniel's Econamine FG process, use $20 \mathrm{wt} \%$ and $30 \mathrm{wt} \%$ MEA solutions as solvents respectively (Rao et al. 2004). MEA has rapid kinetics but requires high regeneration energy (in the range of 3.2-4.2 GJ/tonne $\mathrm{CO}_{2}$ ); the host power plant could be de-rated by more than one-third of its capacity when integrated to a PCC plant with MEA solution as solvent (Fisher et al. 2007). $\mathrm{CO}_{2}$ loaded MEA solution is also very corrosive and degrades rapidly. MEA solution also entails high solvent circulation rate which leads to large equipment sizes and high energy consumption.

These drawbacks of MEA has been addressed through development of new solvents which include mixed amine solvents such as mixtures of MEA and MDEA, AMP and PZ among others (Dubois and Thomas 2012), ammoniabased solvents (Darde et al. 2010), amino acid solvent (Brouwer et al. 2005), biphasic solvents (Raynal et al. 2011) and ionic liquid-based solvents (Boot-Handford et al. 2014; Zacchello et al. 2016). The new solvents have shown great potential. For instance, biphasic solvents require about 50\% less regeneration energy and have about four times cyclic loading capacity compared to MEA (Zhang et al. 2013). Existing commercial PCC processes (see Table 3) use solvents formulated with these new solvents.

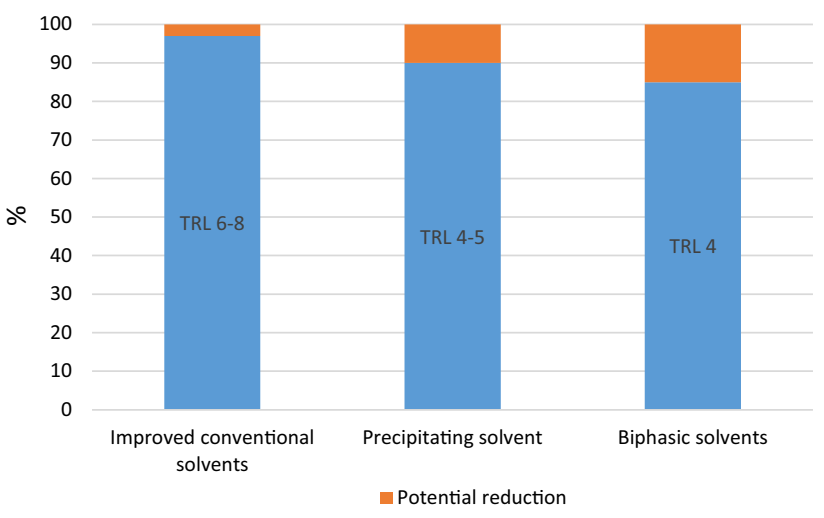

Fig. 3 LCOE scenario for different solvents compared to MEA solvent (IEAGHG 2014)

Notwithstanding the successes with solvent development, analysis of PCC process using improved solvents such as improved conventional solvents (i.e. mixed amine), precipitating solvents (i.e. amino acid) and biphasic solvents among others shows that levelized cost of electricity (LCOE) for a power plant integrated with the PCC process will only reduce by less than $20 \%$ compared to a scenario with MEA solvent (see Fig. 3). The solvents that have shown the greatest potentials namely biphasic solvents are still at development phase with TRL of 4 .

\section{Research and development (R\&D) activities worldwide}

\subsection{Pilot/demonstration PCC plants}

Globally, R\&D activities include laboratory and field scale pilot plants as summarised in Wang et al. (2011) and successful trials of demonstration PCC plants integrated to live power plants (Table 2). The demonstration plants integrated to the power plants via flue gas slipstream have resulted in the development of commercial PCC processes (Table 3).

Another major milestone in PCC development is the European $\mathrm{CO}_{2}$ Test Centre Mongstad (TCM) in Norway. TCM is a specialist centre for testing different PCC technologies, namely Chilled Ammonia and Amine-based PCC processes (TCM 2016). TCM was developed by a consortium involving Gassnova, Statoil, Sasol and Shell, and is estimated to have cost about US\$1.02 billion. Several PCC technologies based on chemical absorption have been tested successfully at TCM, namely Alstom's Chilled Ammonia Process (CAP ${ }^{\mathrm{TM}}$ ), Aker's Clean Carbon, Shell's CanSolv $^{\mathrm{TM}}$ and Siemens' PostCap ${ }^{\mathrm{TM}}$ among others.

A generic independent verification protocol (IVP) developed by Electric Power Research Institute (EPRI) has been used as an independent benchmark for assessing the 
Table 2 Summary of trials of PCC based on chemical absorption process integrated to live power plants

\begin{tabular}{|c|c|c|c|c|c|}
\hline Project & Location & Consortium & Cost & Capacity & Year \\
\hline $\begin{array}{l}\text { Pleasant Prairie (Alstom } \\
\text { 2009) }\end{array}$ & Wisconsin, USA & $\begin{array}{l}\text { Alstom Power/Electric Power } \\
\text { Research Institute/We Energies }\end{array}$ & US\$8.6 M & $15,000 \mathrm{tCO}_{2} /$ year & 2008-2009 \\
\hline $\begin{array}{l}\text { E.ON Karlshamn (MIT } \\
\text { 2016a) }\end{array}$ & Malmo, Sweden & $\begin{array}{l}\text { E.ON Thermal Power/Alstom } \\
\text { Power }\end{array}$ & US\$15 M & $15,000 \mathrm{tCO}_{2} /$ year & 2009-2010 \\
\hline $\begin{array}{l}\text { AEP Mountaineer (Alstom } \\
\text { 2011) }\end{array}$ & $\begin{array}{l}\text { West Virginia, } \\
\text { USA }\end{array}$ & $\begin{array}{l}\text { American Electric Power (AEP)/ } \\
\text { Alstom Power/RWE/NETL/ } \\
\text { Battelle Memorial Institute }\end{array}$ & US\$668 M & $100,000 \mathrm{tCO}_{2} /$ year & 2009-2011 \\
\hline $\begin{array}{l}\text { Brindisi (Mangiaracina } \\
\text { 2011) }\end{array}$ & Brindisi, Italy & Enel and Eni. & $€ 20 \mathrm{M}$ & $8000 \mathrm{tCO}_{2} /$ year & 2010-2012 \\
\hline Plant Barry (MIT 2016b) & Alabama, USA & $\begin{array}{l}\text { Southern Energy/Mitsubishi } \\
\text { Heavy Industries/Southern } \\
\text { Company/U.S. DOE's Southeast } \\
\text { Regional Carbon Sequestration } \\
\text { Partnership and EPRI }\end{array}$ & Unknown & $500 \mathrm{tCO}_{2} /$ day & 2011-2012 \\
\hline Gaobeidian (Ju 2015) & Beijing, China & Huaneng Power Group/CSIRO & Unknown & $3000 \mathrm{tCO}_{2} /$ year & $\begin{array}{l}2008 \text { to } \\
\text { present }\end{array}$ \\
\hline $\begin{array}{l}\text { Shidongkou (Ju 2015; MIT } \\
\text { 2016d) }\end{array}$ & Shanghai China & Huaneng Power Group & US\$24 M & $120,000 \mathrm{tCO}_{2} /$ year & $\begin{array}{l}2010 \text { to } \\
\text { present }\end{array}$ \\
\hline Shenhua (Ju 2015) & $\begin{array}{l}\text { Inner Mongolia, } \\
\text { China }\end{array}$ & Shenhua Group & Unknown & $100,000 \mathrm{tCO}_{2} /$ year & 2010-2014 \\
\hline Sinopec (Ju 2015) & Shangdong, China & Sinopec Group & Unknown & $40,000 \mathrm{tCO}_{2} /$ year & 2010-2012 \\
\hline $\begin{array}{l}\text { Boryeong (Lee et al. 2015; } \\
\text { MIT 2016e) }\end{array}$ & $\begin{array}{l}\text { Boryeong, S. } \\
\text { Korea }\end{array}$ & $\begin{array}{l}\text { Korea Electric Power Company } \\
\text { (KEPCO) }\end{array}$ & US\$42 M & $\begin{array}{l}\left.2 \mathrm{tCO}_{2} / \text { day (Phase } 1\right) \\
200 \mathrm{tCO}_{2} \text { /day (Phase 2) }\end{array}$ & 2010-2013 \\
\hline $\begin{array}{l}\text { Wilhelmshaven (Radgen } \\
\text { et al. 2014) }\end{array}$ & Bremen, Germany & Fluor/E.ON Kraftwerke & Unknown & $70 \mathrm{tCO}_{2} /$ day & 2012-2014 \\
\hline $\begin{array}{l}\text { CCSPilot100+ (Fitzgerald } \\
\text { et al. 2014) }\end{array}$ & Ferrybridge, UK & SSE/Doosan Babcock/Vattenfall & $£ 21 \mathrm{M}$ & $100 \mathrm{tCO}_{2} /$ day & 2012-2013 \\
\hline $\mathrm{ECO}_{2}$ (Powerspan 2016) & Burger & $\begin{array}{l}\text { First Energy/Powerspan/Ohio Coal } \\
\text { Development Office }\end{array}$ & Unknown & $20 \mathrm{tCO}_{2} /$ day & $2008-2010$ \\
\hline Aberthaw (MIT 2016f) & Wales & $\begin{array}{l}\text { RWE npower/CanSolv } \\
\text { Technologies Inc. }\end{array}$ & Unknown & $50 \mathrm{tCO}_{2} /$ day & 2013-2014 \\
\hline Pikes Peak (MIT 2016g) & Saskatchewan & Husky Energy Inc./ $/ \mathrm{CO}_{2}$ Solutions & US\$12.13 M & $15 \mathrm{tCO}_{2} /$ day & 2015 \\
\hline EDF (Chopin 2014) & Le Havre, France & $\begin{array}{l}\text { EDF/Veolia/Alstom Power/Dow } \\
\text { Chemical }\end{array}$ & $€ 22 \mathrm{M}$ & $25 \mathrm{tCO}_{2} /$ day & 2013-2014 \\
\hline
\end{tabular}

process performance in some of the pilot plant tests (Alstom 2009, 2011; Chopin 2014; Thimsen et al. 2014; MIT 2016b). In most of the tests, $\mathrm{CO}_{2}$ capture level up to $90 \%$ and average steam consumption of 1 ton/ton $\mathrm{CO}_{2}$ were reportedly achieved. During the tests, $\mathrm{CO}_{2}$ captured is either vented into the atmosphere (Alstom 2009, 2011; Chopin 2014), transported and stored underground ( $\mathrm{Ju}$ 2015; MIT 2016b) or sold to beverage industries (Ju 2015). Investigations carried out during the pilot plant studies include (1) profiling different solvents; (2) scale-up procedure; (3) solvent degradability; (4) corrosion studies; (5) operation study and (6) process energy efficiency (Chi and Rochelle 2002; Uyanga and Idem 2007; Davis and Rochelle 2009; Kittel et al. 2009; Mangalapally et al. 2009; Alstom 2011; Faber et al. 2011; Seibert et al. 2011; Rabensteiner et al. 2014).

\subsection{Modelling and simulation}

\subsubsection{Model development}

Dynamic models of stand-alone absorber (Posch and Haider 2013; Kvamsdal et al. 2009; Kvamsdal and Rochelle 2008; Khan et al. 2011; Lawal et al. 2009a) and stand-alone stripper (Lawal et al. 2009b; Zaii et al. 2009) which are the main components of the PCC process based on chemical absorption are available in literature. The dynamic models of the complete process including the absorber and stripper are also available (Lawal et al. 2010; Harun et al. 2011; Gáspár and Cormoş 2011; MacDowell et al. 2013; Flø et al. 2015). Two-film theory is used in most of the models to represent rate-based mass transfer. Some papers such as Posch and Haider (2013) used equilibrium-based approach 
Table 3 Commercial PCC based on chemical absorption processes

\begin{tabular}{|c|c|c|c|c|}
\hline PCC process & Developer & Solvent & Demonstration & Commercial project \\
\hline CanSolv $^{\circledR}$ (Shaw 2009) & Shell & Amine-based & $\begin{array}{l}\text { TCM Norway } \\
\text { Aberthaw PCC Wales }\end{array}$ & $\begin{array}{l}\text { Boundary Dam Canada } \\
\text { (Operational) } \\
\text { Bow City Canada (Planning) }\end{array}$ \\
\hline $\begin{array}{l}\text { Advanced Capture Process } \\
\quad \text { (Nustad 2012) }\end{array}$ & Aker Clean Carbon & Amine-based & TCM Norway & $\begin{array}{l}\text { Longannet UK (Cancelled) } \\
\text { Porto Tolle Italy (Cancelled) }\end{array}$ \\
\hline PostCap $^{\mathrm{TM}}$ (Siemens 2015) & Siemens & Amino acid salt & $\begin{array}{l}\text { TCM Norway } \\
\text { Big Bend PCC Florida }\end{array}$ & $\begin{array}{l}\text { ROAD Netherlands (Planning) } \\
\text { Masdar Abu Dhabi (Planning) }\end{array}$ \\
\hline $\begin{array}{l}\text { Econamine FG Plus } \\
\text { (Reddy et al. 2008) }\end{array}$ & FLOUR & Amine-based & $\begin{array}{l}\text { TCM Norway } \\
\text { Wilhelmshaven PCC } \\
\text { Germany }\end{array}$ & Trailblazer, Texas (Cancelled) \\
\hline $\begin{array}{l}\text { Advanced Amine Process } \\
\text { (Chopin 2014) }\end{array}$ & $\begin{array}{l}\text { Alstom Power/Dow } \\
\text { Chemical }\end{array}$ & $\begin{array}{l}\text { DOW } \\
\text { UCARSOL } \\
\text { FGC } 3000\end{array}$ & $\begin{array}{l}\text { EDF PCC Le Havre, France } \\
\text { Charleston PCC, West } \\
\text { Virginia }\end{array}$ & $\begin{array}{l}\text { Elektownia Belchatow, Poland } \\
\quad \text { (Planning) } \\
\text { GETICA Romania (on-hold) }\end{array}$ \\
\hline $\begin{array}{l}\text { CAP }^{\circledR} \text { (Alstom 2009, 2011; } \\
\quad \text { MIT 2016a) }\end{array}$ & Alstom Power & Chilled ammonia & $\begin{array}{l}\text { TCM Norway } \\
\text { Pleasant Prairie PCC } \\
\text { Milwaukee } \\
\text { Karlshamn PCC Sweden } \\
\text { Mountaineer CCS Phase I, } \\
\text { West Virginia }\end{array}$ & $\begin{array}{l}\text { AEP Mountaineer CCS Phase II, } \\
\text { West Virginia (Cancelled) } \\
\text { Project Pioneer Alberta (Cancelled) }\end{array}$ \\
\hline $\mathrm{KM}^{-C D R}{ }^{\mathrm{TM}}$ (MIT 2016b) & $\mathrm{MHI} / \mathrm{KEPCO}$ & $\begin{array}{l}\text { KS-1 (Hindered } \\
\text { amine) }\end{array}$ & $\begin{array}{l}\text { Plant Barry, Alabama } \\
\text { Plant Yates, Georgia }\end{array}$ & Petro-Nova CCS, Texas (On-going) \\
\hline $\mathrm{ECO}_{2}^{\mathrm{TM}}$ (Powerspan 2016) & Powerspan & Amine-based & Burger PCC, Ohio & \\
\hline $\begin{array}{l}\text { HTC (HTC Purenergy } \\
\text { 2016) }\end{array}$ & $\begin{array}{l}\text { HTC Purenergy/ } \\
\text { Doosan Babcock }\end{array}$ & Amine-based & $\begin{array}{l}\text { International Test Centre, } \\
\text { Canada }\end{array}$ & Antelope Valley CCS, North Dakota \\
\hline $\mathrm{CO}_{2}$ Solution (MIT 2016c) & $\mathrm{CO}_{2}$ Solutions Ltd & $\begin{array}{l}\text { Enzyme-based } \\
\text { solvent }\end{array}$ & $\begin{array}{l}\text { Pikes Peak South PCC, } \\
\text { Saskatchewan, Canada }\end{array}$ & \\
\hline$\underset{2013)}{\mathrm{DMX}^{\mathrm{TM}}}$ (Raynal et al. & IFPEN/PROSERNA & Biphasic solvent & $\begin{array}{l}\text { ENEL's Brindisi Pilot PCC, } \\
\text { Italy }\end{array}$ & \\
\hline $\begin{array}{l}\mathrm{RSAT}^{\mathrm{TM}} \text { (Gayheart et al. } \\
\text { 2012) }\end{array}$ & $\begin{array}{l}\text { Babcock and } \\
\text { Wilcox }\end{array}$ & OptiCap $^{\circledR}$ & & \\
\hline
\end{tabular}

which involves approximate mass transfer calculations. Comparative assessment of rate-based and equilibriumbased models of the process in Lawal et al. (2009a, b) showed that rate-based models give better predictions.

Reaction kinetics are neglected in some of the models (Lawal et al. 2009a, b; Zaii et al. 2009; Lawal et al. 2010; Biliyok et al. 2012; MacDowell et al. 2013). This is based on the assumption that the reactions have rapid kinetics and are able to attain equilibrium. The assumption is valid for cases involving solvents with rapid kinetics such as MEA (Kenig et al. 2001). Reaction kinetics have also been described more accurately by introducing an enhancement factor (Kvamsdal and Rochelle 2008; Kvamsdal et al. 2009; Gáspár and Cormoş 2011; Harun et al. 2011; Khan et al. 2011; Flø 2015) or using actual reaction kinetics model (Aboudheir et al. 2003; Posch and Haider, 2013).

Dynamic models by Lawal et al. (2009a, b), Lawal et al. (2010), Gáspár and Cormoş (2011) and MacDowell et al.
(2013) were validated at steady state conditions only over limited conditions at pilot scale due to lack of experimental data for detailed validations as at the time of their publications (Chikukwa et al. 2012). Validation of dynamic models under state steady state and dynamic conditions have also been attempted by Biliyok et al. (2012). The validation results showed good agreement.

The models were used to study the sensitivities of key process variables (e.g. capture level, solvent loading) at different operating conditions under steady state and dynamic scenario and phenomena such as temperature bulge in the absorber (Kvamsdal and Rochelle 2008). More extensive pilot PCC plant data logs (steady state and dynamic) acquired from different PCC demonstration plants namely Brindisi $\mathrm{CO}_{2}$ capture pilot plant (Italy) and TCM (Norway) are now available (Flø 2015). Brindisi and TCM are significantly large scale compared to the pilot PCC plant at University of Texas, Austin (Dugas 2006), the 
capture facility at NTNU laboratory in Gløshaugen, Trondheim and the capture facility at SINTEF laboratory in Tiller, Trondheim among others where data used for validating most models were obtained (Lawal et al. 2010; Biliyok et al. 2012; Flø et al. 2015). The new data have been used to validate dynamic models by Flø et al. (2015) under steady state and dynamic conditions.

\subsubsection{Commercial tools for model development}

Available commercial tools for developing PCC models include Aspen Plus/Custom Modeller developed by Aspen Technology Inc., USA (Zhang et al. 2009) and gCCS developed by a consortium headed by PSE Ltd, UK (Rodríguez et al. 2014). Both applications are CAPEOPEN compliant and supports rigorous thermodynamic models, namely eNRTL and SAFT-VR among others. The gCCS platform also supports modelling and simulation of all components of the CCS chain (i.e. power plant, solventbased capture plant, $\mathrm{CO}_{2}$ compression and pipeline transport, and underground storage). It was selected to be used for the Front-End Engineering (FEED) study of the planned commercial-scale Peterhead CCS in Scotland (PSE 2014) which is now suspended indefinitely (BBC 2015).

\section{Commercial deployment}

Commercial $\mathrm{CO}_{2}$ absorption/stripping plants within CCS context are widely deployed in industries; Sleipner CCS Norway, In Salah CCS Algeria, Snøhvit CCS Norway (Eiken et al. 2010; Ringrose et al. 2013) and more recently, Gorgon CCS Australia and Quest CCS Canada (Shell 2015). However, in power plants, Boundary Dam CCS Canada is the only operational CCS project that is based on chemical absorption process (Stéphenne 2014; SaskPower 2016). The plant was built at a total cost of US $\$ 1.3$ Billion to capture about one million tonnes of $\mathrm{CO}_{2}$ per annum using Shell's CanSolv ${ }^{\circledR}$ PCC process from a re-built 139 MWe (gross) coal-fired power plant. Based on expected revenue from sales of $\mathrm{CO}_{2}$, sulphuric acid and fly ash sales, SaskPower claims that the LCOE of the host power plant is comparable to that of a Natural Gas Combined Cycle (NGCC) Power Plant (Daverne 2012; Clark and Herzog 2014).

There have been mixed reports about the success of the Boundary Dam project. SaskPower claims that the plant achieves up to $90 \%$ capture level when operational (SaskPower 2015). Media reports suggest otherwise claiming that the plant only achieves about $45 \%$ capture level (ENDCOAL 2015; Reneweconomy 2015). Regular mechanical failures have also been reported (Power 2015) and this limited the plant availability to about $40 \%$ during some period (Reneweconomy 2015). During this period, SaskPower could not deliver on their $\mathrm{CO}_{2}$ supply agreement with Cenovus Energy. Recently, SaskPower confirmed nearly $100 \%$ availability for the months of Dec. 2015 and Jan. 2016. It projected an average 85\% availability for the next year (Estevan 2016).

Other power plant-based carbon capture projects across the world such as Petra-Nova CCS, Texas (to be launched later in 2017) are beset with challenges ranging from unfavourable government policies, lack of economic incentives and huge capital cost.

\section{Future research directions}

\subsection{New process}

Currently, the process comprises of large absorber and stripper packed beds which contribute significantly to plant footprint, capital and operating cost. Through process intensification (PI), the size of the absorber and strippers can be reduced significantly (Reay et al. 2013; Wang et al. 2015). In PI equipments such as rotating packed beds (RPBs), the liquid and gas flows are subjected to intense centrifugal acceleration which is many times the gravitational acceleration in conventional packed beds. This allows higher flooding rate and lower interfacial mass transfer resistance resulting in significant reduction in the packed bed sizes. Recent studies have demonstrated prospects of replacing conventional packed beds in PCC with RPB (Agarwal et al. 2010; Joel et al. 2014; Thiels et al. 2016). Agarwal et al. (2010) and Joel et al. (2014) reported 7 and 12 times packing volume reduction respectively for separate cases involving replacement of conventional packed bed with RPB for Absorbers in PCC based on chemical absorption. RPBs have been demonstrated successfully in industry for natural gas desulphurization applications (Fig. 4) (Qian et al. 2012). However, application of RPBs in PCC is still at an early stage of development with many issues, namely scale-up, flooding limit, operating performance and pressure drop, that are yet to be properly understood. This is the focus of an engineering and physical sciences research council (EPSRC) funded research consortium in the UK (EPSRC 2014). Other new designs include spinning disc (EPSRC 2014) and microwave technologies for solvent regeneration. The spinning disc technology involves an RPB and reboiler rotated on the same shaft. This design is currently developed in a UK EPSRC funded project (EPSRC 2014). It's a first-of-itskind design and presents a lot of structural and process design challenges. Microwave technology on the other hand, involves using microwave heating for solvent regeneration instead of steam. Industrial microwave 


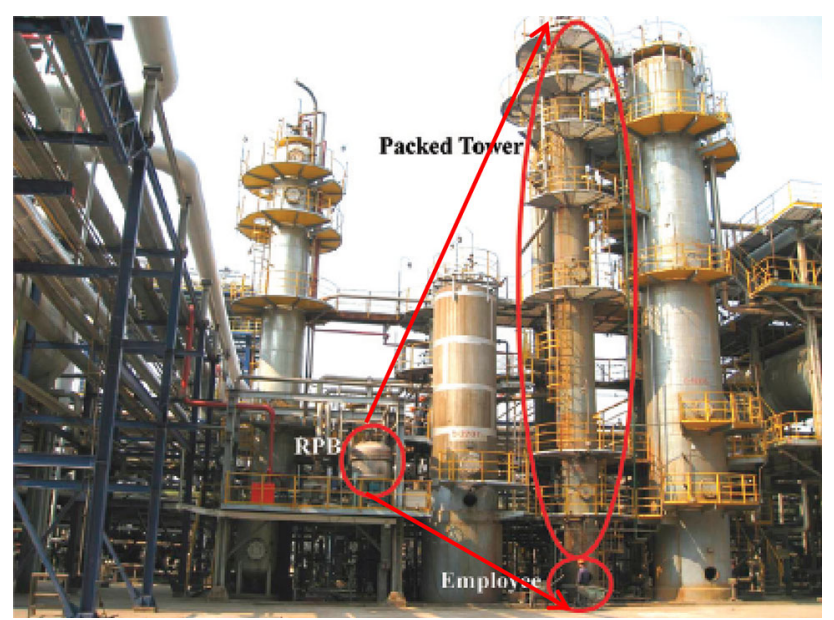

Fig. 4 Commercial demonstration of RPB for desulfurization (Qian et al. 2012)

heating is already a commercial technology (AMT 2016). However, for solvent regeneration, no previous study has been reported. New challenges expected include thermophysical characterisation of the system among others.

\subsection{New solvents}

New solvents with higher $\mathrm{CO}_{2}$ loading capacity and lower regeneration energy could significantly reduce the CAPEX and OPEX of PCC process. Emerging solvents with this potential could be classified as follows:

- Precipitating solvents: An example include amino acid salts such as potassium taurate among others. Technoeconomic analysis of the DECAB process (Versteeg et al. 2003), a patented PCC process with aqueous amino acid salt solvent, indicated that the capital and operating cost is about half that of a similar capacity MEA process (Brouwer et al. 2005).

- Biphasic solvents: These solvents under regulated conditions undergoes liquid-liquid phase separation to give a $\mathrm{CO}_{2}$ lean and rich phases respectively (Raynal et al. 2011). Analysis of $\mathrm{DMX}^{\mathrm{TM}}$ process which uses biphasic solvents shows about 50\% less regeneration energy and lower reboiler temperature compared to the MEA process.

These solvents are largely at an early stage development with TRL of 4 and not yet substantially proven for commercial deployment in PCC applications. There are also issues with them such as dealing with precipitates in the absorber for amino acid salts (Lerche 2012) and regulating phase change behaviour for biphasic solvents (Zhang et al. 2013) which are yet to be properly understood.

\subsection{Combination of new solvents and process}

Emerging solvents are generally viscous and are difficult to handle efficiently in conventional packed bed designs. New packed designs must therefore be developed for these solvents. In a new project (started in Oct. 2016), ROLINCAP (CORDIS 2016), a consortium of 12 partners funded by EU seeks to develop specialized RPBs for biphasic solvents. Biphasic solvents have shown low regeneration energy requirement of about $2.4 \mathrm{GJ} /$ ton of $\mathrm{CO}_{2}$ compared to about $4 \mathrm{GJ} /$ ton of $\mathrm{CO}_{2}$ for MEA (Raynal et al. 2011). RPBs on the other hand have also shown good potential in replacing conventional packed beds.

\section{Conclusions}

PCC based on chemical absorption is a near term technical option for commercial CCS deployment. The technology has been widely validated through pilot plant tests and different aspects of the technology have been investigated through modelling and simulation. Commercial products for modelling and simulation of such processes are now available. The technology can now be purchased off-the-shelf from different vendors namely Shell, Siemens, FLOUR and Alstom.

The technology is already widely deployed in industry but only one large scale commercial carbon capture plant is operating in the power sector. Regardless, the technology CAPEX and OPEX remains unacceptably high. Research in the past decade in this area have been targeted at making the technology more economically-attractive so as to drive its development and deployment. Predicted pathways for research include developing new processes based on PI technology, developing new solvents including precipitating and biphasic solvents and a combination of new processes and new solvents such as the ROLINCAP approach.

Acknowledgements The authors acknowledge financial supports from EU International Research Staff Exchange Scheme (IRSES) (Ref: PIRSES-GA-2013-612230), UK Engineering and Physical Sciences Research Council (EPSRC) (Ref: EP/M001458/2 and EP/ N024672/1) and EU ROLINCAP (Ref: 727503).

Open Access This article is distributed under the terms of the Creative Commons Attribution 4.0 International License (http://creative commons.org/licenses/by/4.0/), which permits unrestricted use, distribution, and reproduction in any medium, provided you give appropriate credit to the original author(s) and the source, provide a link to the Creative Commons license, and indicate if changes were made.

\section{References}

Aboudheir A, Tontiwachwuthikul P, Chakma A, Idem R (2003) Kinetics of the reactive absorption of carbon dioxide in high 
$\mathrm{CO}_{2}$-loaded, concentrated aqueous monoethanolamine solutions. Chem Eng Sci 58:5195-5210

Agarwal L, Pavani V, Rao D, Kaistha N (2010) Process intensification in HiGee absorption and distillation: design procedure and applications. Ind Eng Chem Res 49(100):46-58

Ahn H, Luberti M, Liu Z, Brandani S (2013) Process configuration studies of the amine capture process for coal-fired power plants. Int J Greenh Gas Control 16:29-40

Alstom (2009) We Energies' Pleasant Prairie power plant: pilot project captures $90 \%$ of $\mathrm{CO}_{2}$. http://www.alstom.com/presscentre/2009/10/We-Energies-Pleasant-Prairie-Power-Plant-PilotProject-Captures-90-of-CO2-20091008/. Accessed Feb 2016

Alstom (2011) Alstom announces successful results of Mountaineer Carbon Capture and Sequestration (CCS) Project. http://www. alstom.com/press-centre/2011/5/alstom-announces-sucessful-res ults-of-mountaineer-carbon-capture-and-sequestration-ccs-proje ct/. Accessed Feb 2016

AMT (2016) http://www.advancedmicrowavetechnologies.com/. Accessed Jan 2017

BBC (2015) UK government carbon capture £1bn grant dropped. http://www.bbc.co.uk/news/uk-scotland-scotland-business34357804. Accessed Sept 2015

Biliyok C, Lawal A, Wang M, Seibert F (2012) Dynamic modelling, validation and analysis of post-combustion chemical absorption $\mathrm{CO}_{2}$ capture plant. Int J Greenh Gas Control 9:428-445

Blamey J, Anthony EJ, Wang J, Fennell PS (2010) The calcium looping cycle for large-scale $\mathrm{CO}_{2}$ capture. Prog Energy Combust Sci 36(2):260-279

Boot-Handford ME, Abanades JC, Anthony EJ, Blunt MJ, Brandani S, Mac Dowell N, Fernandez JR, Ferrari M-C, Gross R, Hallett JP, Haszeldine RS, Heptonstall P, Lyngfelt A, Makuch Z, Mangano E, Porter RTJ, Pourkashanian M, Rochelle GT, Shah N, Yao JG, Fennell PS (2014) Carbon capture and storage update. Energy Environ Sci 7:130

Brouwer JP, Feron PHM, ten Asbroek NAM (2005) Amino-acid salts for $\mathrm{CO}_{2}$ capture from flue gases. https://www.netl.doe.gov/ publications/proceedings/05/carbon-seq/Poster\%20147.pdfx. Ac cessed Feb 2016

Carbon Capture and Storage Association (CCSA) (2011) Strategy for CCS in the UK and beyond. http://www.ccsassociation.org. Accessed Aug 2015

Chi S, Rochelle GT (2002) Oxidative degradation of monoethanolamine. Ind Eng Chem Res 41:4178-4186

Chikukwa A, Enaasen N, Kvamsdal HM, Hillestad M (2012) Dynamic modelling of post-combustion $\mathrm{CO}_{2}$ capture using amines-A review. Energy Proced 23:82-91

Chopin F (2014) Results of the $\mathrm{CO}_{2}$ capture demonstration facility at EDF's Le Havre power plant: status of ALSTOM's advanced amines process. PowerGen Europe 2014, Cologne, Germany 3 June

Clark VR, Herzog HJ (2014) Can "stranded" fossil fuel reserves drive CCS deployment? Energy Proc 63:7261-7271

CORDIS (2016) ROLINCAP. http://cordis.europa.eu/project/rcn/ 205819_en.html. Accessed Oct 2016

Darde V, Thomsen K, Van Well WJM, Stenby EH (2010) Chilled ammonia process for $\mathrm{CO}_{2}$ capture. Int $\mathrm{J}$ Greenh Gas Control 4(2):131-136

Daverne D (2012) Integrated carbon capture and storage demonstration: boundary dam power station. In: CCS cost work. Global CCS Institute. http://sequestration.mit.edu/pdf/2012_Costs_ Workshop_Proceedings.pdf. Accessed Feb 2016

Davis J, Rochelle G (2009) Thermal degradation of monoethanolamine at stripper conditions. Energy Proc 1(1):327-333

Dubois L, Thomas D (2012) Screening of aqueous amine-based solvents for post-combustion $\mathrm{CO}_{2}$ capture by chemical absorption. Chem Eng Technol 35(3):513-524
Dugas ER (2006) Pilot plant study of carbon dioxide capture by aqueous monoethanolamine. MSE Thesis. University of Texas at Austin

Eiken O, Ringrose P, Hermanrud C, Nazarian B, Torp T (2010) Lessons learned from 14 years of CCS operations: Sleipner, In Salah and Snøhvit. In: 10th international conference on greenhouse gas technologies, 19-23 September 2010, Amsterdam, Netherlands

ENDCOAL.ORG (2015) Boundary Dam CCS hype goes up in a puff of green smoke. http://endcoal.org/2015/11/boundary-dam-ccshype-goes-up-in-a-puff-of-green-smoke/. Accessed Feb 2016

EPSRC (2014) http://gow.epsrc.ac.uk/NGBOViewGrant.aspx?Gran tRef=EP/M001458/1. Accessed Jan 2017

Estevan Mercury (2016) BD3 operated as advertised in January. http://www.estevanmercury.ca/news/business-energy/bd3-oper ated-as-advertised-in-january-1.2173858. Accessed Feb 2016

Faber R, Kopcke M, Biede O, Knudsen JN, Andersen J (2011) Openloop step responses for the MEA post-combustion capture process: experimental results from the Esbjerg pilot plant. Energy Proc 4:1427-1434

Fisher KS, Searcy K, Rochelle GT, Ziaii S, Schubert C (2007) Advanced amine solvent formulations and process integration for near-term $\mathrm{CO}_{2}$ capture success. Final report under DOE Grant DE-FG02-06ER84625, June 28, 2007

Fitzgerald FD, Hume SA, McGough G, Damen K (2014) Ferrybridge CCPilot100+ operating experience and final test results. Energy Proc 63:6239-6251

Flø NE (2015) Post-combustion absorption-based $\mathrm{CO}_{2}$ capture: modelling, validation and analysis of process dynamics. PhD Thesis Norwegian University of Science and Technology

Flø NE, Knuutila H, Kvamsdal HM, Hillestad M (2015) Dynamic model validation of the post-combustion $\mathrm{CO} 2$ absorption. Int $\mathrm{J}$ Greenh Gas Control 41:127-141

Gáspár J, Cormos A (2011) Dynamic modelling and validation of absorber and desorber columns for post-combustion $\mathrm{CO}_{2}$ capture. Comput Chem Eng 35(10):2044-2052

Gayheart JW, Moorman SA, Parsons TR, Poling CW, Guan X, Wheeldon JM (2012) B\&W PGG's RSAT ${ }^{\mathrm{TM}}$ process and field demonstration of the OptiCap ${ }^{\circledR}$ advanced solvent at the U.S.DOE's National Carbon Capture Centre. Power Plant Air Pollutant Control "MEGA" Symposium, Baltimore, Maryland, USA. August 20-23, 2012

Harun N, Douglas PL, Ricardez-Sandoval L, Croiset E (2011) Dynamic simulation of MEA absorption processes for $\mathrm{CO}_{2}$ capture from fossil fuel power plant. Energy Proc 4:1478-1485

HTC Purenergy (2016) http://www.htcenergy.com/?page_id=607

IEAGHG (2014) Assessment of emerging $\mathrm{CO}_{2}$ capture technologies and their potential to reduce cost. http://www.ieaghg.org/docs/ General_Docs/Reports/2014-TR4.pdf. Accessed Feb 2016

IEAGHG (2015) Integrated Carbon Capture and Storage Project at SaskPower's Boundary Dam Power Station”, 2015/06, August 2015

Intergovernmental Panel on Climate Change (IPCC) (2014) Climate change 2014: mitigation of climate change. Contribution of working group III to the fifth assessment report of the intergovernmental panel on climate change [Edenhofer, O., R. Pichs-Madruga, Y. Sokona, E. Farahani, S. Kadner, K. Seyboth, A. Adler, I. Baum, S. Brunner, P. Eickemeier, B. Kriemann, J. Savolainen, S. Schlömer, C. von Stechow, T. Zwickel and J.C. Minx (eds.)]. Cambridge University Press, Cambridge

IPCC (2005) IPCC special report on carbon dioxide capture and storage. Prepared by working group III of the intergovernmental panel on climate change [Metz, B., O. Davidson, H. C. de Coninck, M. Loos, and L. A. Meyer (eds.)]. Cambridge University Press, Cambridge 
Joel AS, Wang M, Ramshaw C, Oko E (2014) Process analysis of intensified absorber for post-combustion $\mathrm{CO}_{2}$ capture through modelling and simulation. Int J Greenh Gas Control 21:91-100

Ju D (2015) Capability construction of Shanghai CCS research centre. UKCCSRC Strathclyde Biannual Meeting 8-9 Sept, 2015

Kenig EY, Schneider R, Górak A (2001) Reactive absorption: optimal process design via optimal modelling. Chem Eng Technol 56:343-350

Khan FM, Krishnamoorthi V, Mahmud T (2011) Modelling reactive absorption of $\mathrm{CO}_{2}$ in packed columns for post-combustion carbon capture applications. Chem Eng Res Des 89(9):1600-1608

Kittel J, Idem R, Gelowitz D, Tontiwachwuthikul P, Parrain G, Bonneau A (2009) Corrosion in MEA units for $\mathrm{CO}_{2}$ capture: pilot plant studies. Energy Proc 1(1):791-797

Kvamsdal HM, Rochelle GT (2008) Effects of the temperature bulge in $\mathrm{CO}_{2}$ absorption from flue gas by aqueous monoethanolamine. Ind Eng Chem Res 47(3):867-875

Kvamsdal HM, Jakobsen JP, Hoff KA (2009) Dynamic modelling and simulation of a $\mathrm{CO} 2$ absorber column for post-combustion $\mathrm{CO} 2$ capture. Chem Eng Process 48(1):135-144

Lawal A, Wang M, Stephenson P, Yeung H (2009a) Dynamic modelling of $\mathrm{CO}_{2}$ absorption for post combustion capture in coal-fired power plants. Fuel 88(12):2455-2462

Lawal A, Wang M, Stephenson P, Yeung H (2009b) Dynamic modelling and simulation of $\mathrm{CO}_{2}$ chemical absorption process for coal-fired power plants. Comput Aided Chem Eng 27:1725-1730

Lawal A, Wang M, Stephenson P, Koumpouras G, Yeung H (2010) Dynamic modelling and analysis of post-combustion $\mathrm{CO}_{2}$ chemical absorption process for coal-fired power plants. Fuel 89(10):2791-2801

Lee JH, Kwak NS, Lee IY, Jang KR, Lee DW, Jang SG, Kim BK, Shim J-G (2015) Performance and economic analysis of commercial-scale coal-fired power plant with post-combustion $\mathrm{CO}_{2}$ capture. Korean J Chem Eng 32(5):800-807

Lerche BM (2012) $\mathrm{CO}_{2}$ Capture from Flue gas using Amino acid salt solutions. PhD Thesis, Technical University of Denmark

MacDowell N, Samsatli NJ, Shah N (2013) Dynamic modelling and analysis of an amine-based post-combustion $\mathrm{CO}_{2}$ capture absorption column. Int J Greenh Gas Control 12:247-258

Mangalapally HP, Notz R, Hoch S, Asprion N, Sieder G, Garcia H, Hasse $H$ (2009) Pilot plant experimental studies of post combustion $\mathrm{CO}_{2}$ capture by reactive absorption with MEA and new solvents. Energy Proc 1(1):963-970

Mangiaracina A (2011) Enel $\mathrm{CO}_{2}$ post-combustion capture project: Brindisi pilot plant. http://hub.globalccsinstitute.com/sites/ default/files/publications/77416/enel-co2-post-combustion-captu re-project-brindisi-pilot-plant.pdf. Accessed Feb 2016

MIT CCS (2016a) E.ON Karlshamn Fact Sheet: carbon dioxide capture and storage project. http://sequestration.mit.edu/tools/ projects/eon_karlshamn.html. Accessed Feb 2016

MIT CCS (2016b) Plant Barry Factsheet: carbon dioxide capture and storage. https://sequestration.mit.edu/tools/projects/plant_barry. html. Accessed Feb 2016

MIT CCS (2016c) Pikes Peak South Fact Sheet: carbon dioxide capture and storage project. https://sequestration.mit.edu/tools/ projects/pikes_peak.html. Accessed Feb 2016

MIT CCS (2016d) Shidongkou Fact Sheet: carbon dioxide capture and storage project. https://sequestration.mit.edu/tools/projects/ shidongkou.html. Accessed Feb 2016

MIT CCS (2016e) Boryeong Station Fact Sheet: carbon dioxide capture and storage project. https://sequestration.mit.edu/tools/ projects/kepco.html. Accessed Feb 2016
MIT CCS (2016f) Aberthaw Fact Sheet: carbon dioxide capture and storage project. https://sequestration.mit.edu/tools/projects/ aberthaw.html. Accessed Feb 2016

MIT CCS (2016g) E.ON Karlshamn Fact Sheet: carbon dioxide capture and storage project. http://sequestration.mit.edu/tools/ projects/eon_karlshamn.html. Accessed Feb 2016

Nustad JH (2012) Aker Clean Carbon's carbon capture technology and projects. CCS Technology Club Meeting 14 Nov., 2012. http://www.tuvnel.com/_x901bm/4-Aker_Solutions.pdf. Accessed Feb 2016

Olaleye AK, Wang M (2014) Techno-economic analysis of chemical looping combustion with humid air turbine power cycle. Fuel 124:221-231

Posch S, Haider M (2013) Dynamic modelling of $\mathrm{CO}_{2}$ absorption from coal-fired power plants into an aqueous monoethanolamine solution. Chem Eng Res Des 91(6):977-987

Power (2015) SaskPower Admits to Problems at First "Full-Scale" Carbon Capture Project at Boundary Dam Plant. http://www. powermag.com/saskpower-admits-to-problems-at-first-full-scalecarbon-capture-project-at-boundary-dam-plant/. Accessed Sept 2016

Powerspan (2016) Independent review of $\mathrm{ECO}_{2}$-Pilot Assessment and Scale-Up analysis. http://powerspan.com/technology/eco2co2-capture/independent-review-of-eco2/. Accessed Feb 2016

PSE Ltd (2014) New gCCS system modelling technology used for Shell Peterhead Project. http://www.psenterprise.com/news/ press_releases/140731_shell_peterhead/index.html. Accessed Feb 2016

Qian Z, Li Z, Guo K (2012) Industrial applied and modelling research on selective $\mathrm{H}_{2} \mathrm{~S}$ removal using a rotating packed bed. Ind Eng Chem Res 51:8108-8116

Rabensteiner M, Kinger G, Koller M, Hochenauer C (2014) Three years of working experience with different solvents at a realistic post combustion capture pilot plant. Energy Proc 63:1578-1584

Radgen P, Rode H, Reddy S, Yonkoski J (2014) Lessons learned from the operation of a 70 tonne per day post combustion pilot plant at the coal fired power plant in Wilhelmshaven, Germany. Energy Proc 63:1585-1594

Rao AB, Rubin ES, Berkenpas MB (2004) An integrated modelling framework for carbon management technologies, volume 1technical documentation: amine-based $\mathrm{CO}_{2}$ capture and storage systems for fossil fuel power plant. U.S. Department of Energy National Energy Technology Laboratory. https://www.cmu.edu/ epp/iecm/documentation/tech_04.pdf. Accessed Sept 2015

Raynal L, Alix P, Bouillona P-A, Gomez A, de Nailly MLF, Jacquin M, Kittel J, di Lella A, Mougin P, Trapy J (2011) The DMX ${ }^{\mathrm{TM}}$ process: an original solution for lowering the cost of postcombustion carbon capture. Energy Proc 4:779-786

Raynal L, La Marca C, Normand L, Broutin P (2013) Demonstration of the $\mathrm{DMX}^{\mathrm{TM}}$ process-description of the Octavius SP3 project. In: 2 nd post combustion capture conference $17^{\text {th }}-20$ th September 2013, Bergen, Norway

Reay D, Ramshaw C, Harvey A (2013) Process intensification: engineering for efficiency, sustainability and flexibility. Butterworth-Heinemann, Oxford

Reddy S, Johnson D, Gilmartin J (2008) Fluor's Econamine FG PlusSM technology for $\mathrm{CO}_{2}$ capture at coal-fired power plants. In: Presented at Power Plant Air Pollutant Control "Mega" symposium August 25-28, 2008 Baltimore

Reneweconomy (2015) The fallout from SaskPower's Boundary Dam CCS debacle. http://reneweconomy.com.au/2015/the-falloutfrom-saskpowers-boundary-dam-ccs-debacle-54803. Accessed Feb 2016 
Ringrose PS, Mathieson AS, Wright IW, Selama F, Hansen O, Bissell R, Saoula N, Midgley J (2013) The In Salah $\mathrm{CO}_{2}$ storage project: lessons learned and knowledge transfer. Energy Proc 37:6226-6236

Rodríguez J, Andrade A, Lawal A, Samsatli N, Calado M, Ramos A Lafitte T, Fuentes J, Pantelides CC (2014) An integrated framework for the dynamic modelling of solvent-based $\mathrm{CO}_{2}$ capture processes. Energy Proc 63:1206-1217

SaskPower (2015) CCS performance data exceeding expectations at world-first Boundary Dam Power Station Unit \#3. http://www. saskpower.com/about-us/media-information/news-releases/ccsperformance-data-exceeding-expectations-at-world-first-bound ary-dam-power-station-unit-3/. Accessed Feb 2016

SaskPower (2016) Boundary Dam Capture Project. http://saskpo werccs.com/ccs-projects/boundary-dam-carbon-capture-project/. Accessed Feb 2016

Seibert F, Chen E, Perry M, Briggs M, Montgomery R, Rochelle G (2011) UT/SRP $\mathrm{CO}_{2}$ capture pilot plant-operating experiences and procedures. Energy Proc 4(2011):1616-1623

Shaw D (2009) CanSolv $\mathrm{CO}_{2}$ capture: the value of integration. Energy Proc 1:237-246

Shell (2015) Shell launches quest carbon capture and storage project. http://www.shell.com/media/news-and-media-releases/2015/she 11-launches-quest-carbon-capture-and-storage-project.html\#vani ty-aHR0cDovL3d3dy5zaGVsbC5jb20vZ2xvYmFsL2Fib3V0c2 hlbGwvaW52ZXN0b3IvbmV3cy1hbmQtbGlicmFyeS8yMDE1 L3NoZWxsLWxhdW5jaGVzLXF1ZXNOLWNhcmJvbi1jYXB OdXJILWFuZC1zdG9yYWdlLXByb2plY3QuaHRtbA. Accessed Feb 2016

Siemens AG (2015) http://www.energy.siemens.com/nl/en/fossilpower-generation/power-plants/carbon-capture-solutions/postcombustion-carbon-capture/. Accessed Feb 2016

Stéphenne K (2014) Start-up of world's first commercial postcombustion coal fired CCS project: contribution of Shell Cansolv to SaskPower Boundary Dam ICCS Project. Energy Proc 63(2014):6106-6110
TCM (2016) http://www.tcmda.com/en/

Thiels M, Wong DSH, Yu C-H, Kang J-L, Jang SS, Tan C-S (2016) Modelling and design of carbon dioxide absorption in rotating packed bed and packed column. In: 11th IFAC symposium on dynamics and control of process systems, including biosystems June 6-8, 2016. NTNU, Trondheim, Norway

Thimsen D, Maxson A, Smith V, Cents T, Falk-Pedersen O, Gorset O, Hamborg ES (2014) Results from MEA testing at the $\mathrm{CO}_{2}$ Technology Centre Mongstad. Part I: post-combustion $\mathrm{CO}_{2}$ capture testing methodology. Energy Proc 63:5938-5958

Uyanga IJ, Idem RO (2007) Studies of $\mathrm{SO}_{2^{-}}$and $\mathrm{O}_{2}$-induced degradation of aqueous MEA during $\mathrm{CO}_{2}$ capture from power plant flue gas streams. Ind Eng Chem Res 46(8):2558-2566

Versteeg GF, Kumar PS, Hogendoorn JA, Feron PHM (2003) Method for absorption of acid gases. International patent WO 03/095071 A1

Wang M, Lawal A, Stephenson P, Sidders J, Ramshaw C (2011) Postcombustion $\mathrm{CO}_{2}$ capture with chemical absorption: a state-ofthe-art review. Chem Eng Res Des 89(9):1609-1624

Wang M, Joel AS, Ramshaw C, Eimer D, Musa NM (2015) Process intensification for post-combustion $\mathrm{CO}_{2}$ capture with chemical absorption: a critical review. Appl Energy 158:275-291

Zacchello B, Oko E, Wang M, Fethi A (2016) Process simulation and analysis of carbon capture with an aqueous mixture of ionic liquid and monoethanolamine solvent. Int J Coal Sci Technol. doi:10.1007/s40789-016-0150-1

Zaii S, Rochelle GT, Edgar TF (2009) Dynamic modelling to minimize energy use for $\mathrm{CO}_{2}$ capture in power plants aqueous monoethanolamine. Ind Eng Chem Res 48:6105-6111

Zhang Y, Chen H, Chen C-C, Plaza JM, Dugas R, Rochelle GT (2009) Rate-based process modelling study of $\mathrm{CO}_{2}$ capture with aqueous monoethanolamine solution. Ind Eng Chem Res 48:9233-9246

Zhang J, Qiao Y, Wang W, Misch R, Hussain K, Agar DW (2013) Development of an energy-efficient $\mathrm{CO}_{2}$ capture process using thermomorphic biphasic solvents. Energy Proc 37:1254-1261 